\title{
To Examine Reasons Of Social Media Usage Through Personal And Brand Image Management
}

\author{
Tan, H. ${ }^{1}$ \\ ${ }^{1}$ Hakan TAN, Istanbul Aydin University, (Turkey) \\ e-mail: hakantan@stu.aydin.edu.tr
}

\begin{abstract}
The image is the imagination that emerges as a result of the interaction between the person and others and the objects and life practices. The image of the object leads to the desire to have access to the object, leads to dependency and even compliance, identification and internalization of the object in the process.In this way, the object produced by man is metamorphosed and transformed into an independent entity, and the object acquires identity, personality and self within the process. As for theoreticians, they are explaining this relation as "we are what we have" and "we think what we look at". As for self, it comes into existence as a result of persons interaction with objects and others in social structure and representment of self is accepted as persons image. According to self-theorists, people aim to protect and strengthen their self-image, and use social relations as a means to achieve their goals. People use the image of objects to have the image they desire and manage dramaturgy and impression in their social relations. Thanks to the development of the Internet and technology, the convergence and digitization of communication tools and information technologies has created new media. Peoples desire to socialize and the possibility of technology enabled McLuhan's concept of "global village" and created social media channel. With the help of new media tools, people now join social media, create images, symbols and showings created by artists in Antique Age, Medieval Age and Renaissance, and becoma a media producer. While the people in the social media channel manage image through dramaturgy and impression management, brands manage image with public relations, advertisement and integrated marketing communication applications. Bourdieu refers to the settled place, settlers, habits and processes in the concept "habitus". In this context, study aims to explain the relationship between social media (place of settlement) and those who use social media (settlers) based on the concept of "habitus" and the direction of personal and brand image of habits arising as a result of this relationship and process. The study is written within the scope of doctorate thesis titled "Transformation of personal and brand image management in social media" which is still going on in Istanbul Aydın University and descriptive research method which is applied research method and application of communication science is used.
\end{abstract}

Keywords: Social media, Image, Brand, Self, Image Management

\section{Introduction}

What distinguish humanity from the rest of the living beings on earth and ensured their survival to the modern days is the ability to produce and use communication symbols. In communication, communication applications and communication symbols become prominent. Communication applications are explained as signs, nonverbal communication (body language), parole (auditory image), picture, ideogram, pictogram, symbol, alphabet (writing) and verbal communication. Historically, the means of communicating with other people have been applied with tools such as clay, stones, papyrus, parchment, and with the development of the paper, the invention of the printing press and the development of technology, typists, photographic machines, telegraphy and radio telegraphy, telephone, radio, and these tools are gathered under the roof of the traditional media concept. People can conduct communication applications both mediated and unmediated. According to Oxford English Dictionary, mediated means of communication has been called "media" since the 1920s. "Innis, as a good economic historian, means materials used for communication while using the word" media" (Briggs \& Burke, 2004: 13). The media concept is described as the display of personal and corporate 
communication productions in a technological tool. Nowadays the media is described as the fourth force after judicial, legislative and executive. According to Lazar (2009: 12) and Gerbner (2010: 91), the main issue of communication is the media. Although communication is accepted as science in the 20th century, communication has always been intertwined with human, natural and axiometry sciences. Communication has attracted the attention of thinkers since Antique Age. Aristotle, in Rhetoric, draws attention to the importance of the source, the reliability of the source, the image of the source in the receiver, the message formed by the source, the encoding of the message, the content of the message, the plausibility of the message with ethos, logos and pathos. Aristotle's view of communication is linear and he explains rhetoric as the ability to use ways to convince. People in antiquity used rhetoric to influence and persuade masses. It is seen in the theories and models such as "propaganda", "public opinion", "silver bullet", "transportation belt", "hypodermic needle" that the thinkers in the early twentieth century had the same approach to communication as Aristotle. The most important difference in these models and theories is that communication is mediated and mediated communication is called "media" since 1920's. Gustave Le Bon, Walter Lipmann, the Chicago School and its representatives, Dewey, Cooley, Park, Mead and political scientist Harold D. Laswell, Ivy Ledbetter Lee and Edward Bernays, founder of the science of public relations, can be considered important thinkers of the period. The thinkers of the period emphasized the use of the media (mass media) in their works to persuade and influence the masses. Moreover, since the beginning of the twentieth century, communication has been interwoven with behaviorism, sociology, psychology and social psychology and especially works by Ivan Pavlov, John B. Watson, Edward L. Thorndike, and Sigmund Freud on communication influenced the periods thinkers.

The issue of persuading and influencing the masses in the First World War was the most important priority of the states. After the "great depression" crisis of 1929, after World War I, governments' and corporations' need for public relations and advertisement has increased. Thus, communication before and during World War II became the first priority of human scientists. The researches made during this period were presented to the world of science after the war as a theory and model. Wilbur Schramm is one of the pioneers in the establishment of communication science in postwar America. Tokgöz states (2015) that Wilbur Schramm, one of the pioneers in the establishment of communication science in America used the term "founding fathers of the communication science" for Harold D. Laswell, Paul F. Lazarsfeld, Kurt Lewin ve Carl Hovland at an article in 1963 and used the same term in other publications later on. Harold D. Laswell was a political scientist, Paul F. Lazarsfeld was a sociologist / social psychologist and mathematician, and Kurt Lewin and Carl Hovland were social psychologists. We remember Harold D. Laswell with $5 \mathrm{~W}$ Theory, Paul F. Lazarsfeld (With Katz) with two steps flow of communication, Kurt Lewin with gatekeeper and group Dynamics and Carl Howland with works on communication and persuasion. While accepting the importance of founding fathers, we also need to emphasize Shannon and Weaver's Mathematical Communication Theory (1949). According to Shannon and Weaver, the communication process is described as a one-way (linear) transmission of the message from the source to the receiver. However, the root of the term of communication is "communis" in Latin, which means sharing and partnership. In English, term "communication" comes from the word "common". Tokgöz says, "Even if communication is different according to time and space, considering communication as sharing and interaction is unchanged." (Tokgöz, 2015:191). Communication is the interaction, participation, sharing and deduction that occurs as a result of the encoding of symbols with common meaning as unmediated or mediated by the context (media, gutter and channel). Communication is two-way. Traditional media is one-way, even if it has the concept of traditional media feedback. John B. Thompson explains this situation in his article "Some features of mass communication" as "Mass communication usually contains one-sided messages from transmitter to receiver. Unlike the dialogic situation in which mutual talk and listeners are at the same time a potential response, mass communication institutionalizes a fundamental break between producer and receiver; so that the contribution of the receivers to the flow and content of the communication process is relatively small. Hence, it may be more appropriate to speak of "transmission" or "broadcasting" as "communication" in the way we know it" (Thompson, 2010: 210). According to John B. Thompson, if communication is not two sided, it is transmission and broadcasting. To be able to participate and share, there must be no gatekeepers. Kurt Lewis is the one who invented the concept of gatekeeper. When Kurt Lewin (1947) was experimenting with changing the eating habits of families and preventing throwing food away (thinking it was spoiled) at a time of meat shortage in the United States, he considers those who control the information flow as gatekeepers and defends the term gatekeeper. "Gatekeeper functions can be carried out as an informal opinion, as in group trials, or to those who are officially appointed to 
the administrative or editorial Office." (Lang, 2010: 33). Traditional media is one-sided and has gatekeepers, although it has the feedback feature.

Communication on the other hand is interaction and interactivity. In order for unmediated and mediated communication to be interactive, the term "mutual physical / contextual close relationship between two or more people; The ability to interfere with the flow of the program by interacting with a program and the way in which the human interacts with the human-machine interface that actively accepts input from the person " (Baştan, 2009: 8). New communication tools are added with the possibility of communication technology and with the people can communicate with machines through these interfaces. This communication happens with various virtual (software) and concrete (smart mobile, tablet, PC, Laptop etc.) products. People can not have close cooperation and interaction with others in the traditional media and with the author, nor can they intervene in the content. Therefore, the characteristics of the concept of communication are not fully realized in the traditional media.

With the development of the Internet and technology, it has created the concept of new media through the convergence and digitization of communication technologies and information technologies. According to Binark (2014: 15) The new media term is used to describe digital media, especially interactive media, Internet networks and social media, unlike traditional media (books, television and radio). In addition to the concept of new media, people also created social media channel by confirming McLuhan's concept of "global village" by with the need of socialization and technology. According to Boyd and Ellison, social media "are virtual environments in which users create, display, display, share, and observe other users' profiles and relationships, in a totally or partially open profile" (Kara, 2013: 54). According to definitions and researches on social media, brands and users are in interaction and communication in social media channel. Participation in social media channel is rapidly increasing worldwide. For example, Facebook has a penetration of over 1.7, and 1.1 billion people use Facebook every day (URL-1). Freud explains this situation refering to Le Bon as "if individuals have socalized and created a mass, of course, there must be a bond that connects them, and this bond can not be anything other than the characteristic feature of the mass" (Freud, 2012: 11). It is mentioned in the study that the characteristic of the new and social media is effective in the creation of the mass. New and social media is an interactive, participatory, virtual and measurable communication environment. In addition, according to research, it is an environment in which people show that they are better, more attractive and beautiful than themselves and their lives, and they try to build their reputations (images). In other words, people manage image in social media channel. Thus, people create images, symbols and showings created by artists in Antique Age, Medieval Age and Renaissance, and becoma a media producer. While the people in the social media channel manage image through dramaturgy and impression management, brands manage image with public relations, advertisement and integrated marketing communication applications.

\section{Social Media Concept}

The definition of communication takes place in social media. Features that distinguish social media from traditional media are it being two-sided, interactive, participative. If a media environment enables an interactive communication and allows sender and receiver to be both active and passive (participate), it is a social media. According to Fuch "social media- and -web 2.0- in the past years; blogs, microblogs like Twitter, social networking sites, or video / image / file-sharing platforms or wikis, have become popular in explaining the types of World Wide Web (WWW) applications" (Fuch, 2016: 49). As for Tasner, he explains Web 2.0 as collaboration, blogging, content sharing, online video, social networks Web 3.0 as mobile browsing, live video broadcasting, microblogging, personalization and semantic terms (Tasner, 2011: 19). In both Fuch and Tasner's definitions, technology allows people to produce, share, interact, collaborate and communicate with social media channel. Today by using a two-way, interactive, sharing and participatory media and using the internet, people can find a job, meet other people, get information, create friendship groups, upload videos they want to social media channels and allow others to watch or watch themselves and transmit news through microblogs to thousands and even millions of people. In addition, people in social media such as Facebook, Wikipedia, Myspace, Twitter, YouTube, Instagram, Pinterest, they can share their thoughts, interests, wishes, curiosities, perceptions voluntarily in these channel and participate, while learning other people's thoughts, likes, desires, curiosities, perceptions. People can Access and convey their likings though Web 2.0 and 3.0 features. Interaction in social networks happens with imagery, writing, sign and symbol images, photo images. Umberto Eco in his European Culture Search for Impeccable Language (2009), he refers to the collapse of the Babylonian tower and the division of humanity and 
the emergence of languages. Most of the people of today's world population participate in social media channel like Facebook and Instagram, to be able to coexist with the mediated communication (media) and to refer to the Babel Tower metaphor with the desire for convergence and unification. On the other hand, people participating in social media applications want to get fame for their self with their imagesharing communication products. Symbolic interaction practices in social networks are being investigated in order to play the roles, the impressions and production of the expressions, in other words the stage of the human being in a scene created by the human being (media) and the presentation of images, symbols and illustrations with the possibilities provided by the technology. The fact that communication is defined in social media channel, how we are presented or how we are exhibited or seen by us, like the same mediatorless communication, leads us to the concept of self, image.

\section{Personal Brand Image Management}

We need to classify the symbols and pictograms according to the images and signs. Symbols and pictograms are more of a denotation. The image and the signs have bot denotation and connotation, and connotation is even more prominent. In his book Symbol (2013), Piercy explains why symbols and pictograms are needed and their meanings through historical, social, economic, cultural, political, military and communication dimensions. Symbols and pictograms are said to have been created with human intelligence by thinkers in terms of functions such as solving, communicating, clarifying, compromising, and removing linguistic differences from a social, economic, cultural, political, military and communicative problem at local, national and international level. However, the communication world thinks that there is no consensus on the image and the signs' connotation. The image is depicted in the minds of individuals as being designed and desired, missed, imagined and dreamy. In Oxford Advanced Learner's Dictionary, image is explainsed as "the image is explained as "the impression given to a person, or a product by the public". (Polat and Arslan, 2015:1).

Chicago School stands out in terms of interaction, symbolic interaction, self, dramaturgy and impression management. University of Chicago was founded by John D. Rockefeller in 1892 . The Chicago School of Sociology and its representatives were influenced by Georg Simmel, William James and Charles Sanders Peirce. Peirce has suggested pragmatism and semiotic theories and is also regarded as the founder of American semiotics. According to Peirce, "Everything is signs (...) Every thought consists of signs, and thinking uses the signs" (Mattelart \& Mattelart, 2011: 27). The concept of perception and perception management, which is increasing in today's world, comes to the forefront in Peirce's view. He draws attention to the person's thoughts, the person, the objects, the goods and the products in his life, influencing or even thinking with them.

William James studied self-theory. Williams James in his Principle of Psychology(1890), not only did he conceptualize the self-theory, but at the same time it is very important to understand human behavior. (Kağıtçıbaşı \& Cemalcılar, 2015: 247). William James claims that self has three basic orientations. These are the material self, the social self, and the spirit self. According to James, "the material self: the person's own body, clothes, family, home, possessions constitute his material self (...) However, one must be identified with this material object; The social self plays an important role in the formation of others' thoughts, our social self. Social self is the end result of people interacting with each other." William James emphasizes that the goods and products possessed by the people are part of the self, and on the other hand, the importance of the social relations with the goods and the products in the formation of the self.

George Herbert Mead, John Dewey, Charles Horton Cooley, and Robert Park, representatives of the Chicago School of Sociology, carried out their Works by centering communication and interaction. For example, according to John Dewey, it is not simply a verbal linkage between the words "common, community and communication, the guarantor of being able to have a common understanding in society is communication" (Morva, 2013: 109). Dewey centers communication on the formation of society by creating a common bond and understanding among the people. Dewey, Park, and Cooley emphasize the importance and impact of communication and interaction in the restructuring of the country and cities where they are influenced by immigration, urbanization and capitalism. One of the representatives of the Chicago School, Cooley explains the concept of self through the mirror metaphor. According to Cooley's mirror metaphor, how one sees himself; How others see the person; What really is yours. Charles Horton Cooley's mirror metaphor has evolved into the self-theory by George Herbert Mead. "According to Mead, self is an actor" (Wallace \& Wolf, 2015: 276). Mead recognizes self as an actor and the self is formed within the processes of communication, interaction and cooperation with other people, in other words within a social structure. 
Goffman conceptualized the presentation of self as William Shakespeare's "the world is a theater", taking the image as the dramaturgical approach staged in the theater. Erving Goffman in his "Presentation of Self in Everyday Life", examines the impressions and expressions of the creatures through symbolic interaction rather than verbal communication. "Dramaturgical analysis is in harmony with its symbolic motivational origins. Actors focus on action and interaction" (Ritzer \& Stepnisky, 2014: 219). "As Goffman shows, social interactions often involve putting a "self on the stage" where everyone tries to adopt and maintain a respectable image of himself, regarded as a social identity" (Bourse \& Yücel, 2012: 269). Goffman explains that concepts of image and self can be used in the others place as follows "The self staged in this work is considered an (often reliable) image that the individual who plays a certain character on stage tried to give to others" (Goffman, 2014: 234). The self becomes the result of the interaction with the others in the social structure and the objects, and the presentation of the self is regarded as the image of the person. According to self-theorists, people aim to protect and strengthen their self-image, and use social relations as a means to achieve their goals. People use the image of objects to have the image they desire, and manage dramaturgy and impression in their social relations. Among personality features and images that the person thinks he possesses, personality traits and images, and other people's thoughts about himself, and others' thoughts about the individual; The person is trying to build who they are (personality/self). This leads us to concepts of personality / self which are possessed and desired. Fromm criticizes the situation as follows: "People are now struggling to be sold in the best possible way, not for their own lives and happiness. (...) The main principle is: "I am like you want to have me" (Fromm, 2015a: 186). In addition, Goffman emphasizes the concept of mask. It is probably not a simple historical coincidence that the first meaning of the word "person" is the "mask" (...) In the end, our understanding of the present day is an inseparable part of our personality. We come to this world as individuals, we gain personality and we become one person" (Goffman, 2014: 31 from Park, 1950: 249).

Only $7 \%$ of how we perceive people is related to the content, and almost all of our other perceptions are related to the image, which leads people to attach importance to images too. "Image thought; is one of the keys of your sphere of thought, learning deep guiding, guiding and using the people as you wish" (Guiraud, 1990: 98). People have long been aware of the importance of images and perceptions. After describing the concept of happiness in Rhetoric, Aristotle explains the parts that make up the concept of happiness as: "a noble birth, a large number of friends, good friends, being, good children, a large number of children, a happy old age and at the same time good health with honor, luck and virtue, beauty, power, size, athletic power, etc." (Aristotle, 2016: 49). According to Aristotle, it is understood that the parts that constitute happiness come to the fore of the concepts of body, body, fame, progeny, multiplicity of friends, friendship, existence, honor and virtue. The concepts of self and image are related to each other and each can almost not be explained without the other. Mead refuses to distinguish people from the objects they perceive, and perceiving the object makes it an object for a person; perception and object can not be separated (there is a dialectical relation to each other) (Ritzer, 2008: 216). Mead draws attention to the importance of thinking together the images possessed and / or possessed by the concept of self and the images they possess.

\section{The Relationship The Person And The New Medium}

With the development of technology, communication and information technologies can be gathered in a single tool, and one of these tools is smart mobile phones. By allowing the intelligent mobile phones to transmit digital voice and data, the contacts can perform both verbal communication, connect to the Internet and social media channel as well as transfer data. With new media tools, people can have both concrete products (smart phones) and abstract products (software/social media channels). In McLuhan's Gutenberg Galaxy, he refers to William Blake's "They became what they see" and says "Blake makes it clear that people change when their sense organs change" (McLuhan, 2014: 369). McLuhan also tried to prove this hypothesis in his works, Gutenberg Galaxy (2014) and Global Village (1992). McLuhan's students and followers are also doing some research to prove that the tool has changed the effect of the message. Blake pointed out the importance of images and images that people are in interaction with people with the words "They became what they see". New media and social media are taking the place of traditional media that people have interacted in the Industrial Revolution. Innis refers to the media with the concept of media, and in today's researches, it is emphasized that the new media tools that people use most are smart media and social media media. The features of the new media can be digitality, virtuality, interactivity, sharing, participation and measurement. Nowadays, people can measure the images they share in their meetings thanks to their smart mobile phones in a two-way and interactive communication environment. Thus, people can learn how many people see, like and even share opinions with other people about the image they 
share. In addition to these, people can also know numerically how many people they follow and how many people they are followed by in new media channel. For people with new media, the message becomes a digital object; The importance of numerical value of the images is also increasing; It leaves the place of oral communication to the contents of the media message; The true identity, personality and self of the people are transformed into virtual identity, personality and self. Today's people are transformed into "what they see" by Blake's statement. In the study, the transformation of people and brands' images used for image management by new media and features of new media is explained.

The Extended Self Theory is explained as "We are what we have." (Belk,1988). According to the expanded self theory, "the goods, the clothes, the jewels, the family members, the photographs, the gifts, the diaries, the memories, the places and the events are part of the self" (Özer, 2014: 419). As McLuhan explains in his works that "the tool is the extension of the body of the person", the extended self theory is also explained as a part and extension of objects that the person has. The extended self theory was developed by Russel Belk. It is based on the work of William James (1890), which also influenced the representatives of the Chicago School in his extended self theory. Belk refers to James, "We are the sum of what we have" (Belk, 1988: 139). Belk argues that with the extended self theory, things that are possessed by a person are pieces of clothing, jewelery, jewelery, family members, photographs, gifts, diaries, memories, places and events as well as valuable objects. Karl Marx describes goods and products with the concept of "meta", and in his book Das Kapital, he emphasizes that the meta-human relationship is "an artifact of man-made products, which is humanlike and transforms into an entity that engages with man" (Berger, 2014: 61). Marx emphasizes that man-made commodities have acquired identity, personality, and self. In addition, in Fromm's "To Have or To Be?" he emphasizes that modern consumers have to express themselves as "nothing other than what I have and have consumed. It is also proposed that the expanded self theory can be the most basic and powerful characteristic of "we are what we have" consumer behavior.

Cohen, in "An Over-Extended Self" (1989) emphasizes and criticizes Belk's lack of meaning, empirical diagnosis, and explanatory power that the extended self theory is so broad and inclusive, purposefully exaggerated, not absolutely right. Cohen refers to various renewable products and states that these products can not be the expanded self of the person. Cohen, on the other hand, notes the great importance of certain objects and products to individuals and emphasizes the feature of being distinctive and narrows the scope of Belk's theory to point to a good point if he emphasizes the personal meaning and value of the precise objects of the extended self (Cohen, 1989: 126). We do not agree with all of Cohen's criticism and suggest that the expanded self theory be narrowed down in the context of man-made goods and products. In Belk's answer to Cohen's criticism in 1989, and in response to Cohen's question, "When does the extended self emerge?" "is emphasized. In relation to the "how" question in the study, public relations are explained as image management realized through applications of advertising and integrated marketing communication.

Belk, in his article entitled The Expanded Self in the Digital World (2013), points out that products and goods undergo major changes in the technology and digitalization framework, thus adding new products and products, and emphasizing that my extended self is still alive. It states that technology and digitalization add "virtual" products, goods, identities, personality and ego to products, goods, identities, personality and ego, and the expanded self in the digital world in its article; Dematerialization; Virtual life (reembodiment); Sharing; Co-construction of self; Explained in the context of distributed memory headers. Belk on the headings above, when the products and goods are turned from concrete to abstract, Because people have a second life with these abstract products; It emphasizes that the self-possessions of the people are transformed into a more collaborative self. Belk emphasizes that research on the extended self is still going on and emphasizes that "the future of technology will lead to a change in the image of possible self and goods" (Belk, 2013: 494). Nowadays, people can not hide their intelligent mobile phones and act as if they are part of their bodies. They connect with smart mobile phones and social media channel, spend time sharing images and managing images.

\section{Brand Concept And Brand Image Management}

According to Marx, the object produced by man is moving away from the person and transforming into an independent entity from the human. The image of the object leads to the desire to have access to the object, leads to dependency and even obedience, identification and acceptance of the object in the process. Today, people call products produced by people brand. The AMA (American 
Marketing Alliance) describes brand as "the name, the term, the mark, the symbol, or other markings of a merchant whose product is distinguishable from the others" (Tosun, 2010: 7, Keler, 2013: 30). According to Keller: brand consists of brand knowledge, brand image and brand awareness and "brand image is perception and priority that customers measured in various types for a brand have associations in memory" (Keller, 2013: 549). According to this definition, the brand is an imagiery in the memories of the customers. On the other hand, the brand is a sign and it points to a sender. $F$ de Saussure explains the term sign as: "We call the combination of the mental image (concept) and the vision image an sign (...) We propose that the sign word should be adopted instead of the used mental image (concept) to indicate the whole" (Vardar, 1999: 31, Rifat, 2014b:24). According to F. De Saussure, the sign is the sum of the signifier and the signified. The brands in the lives of people are also an sign, and the concept of sign consists of signifier (concept / expression) and signified (content / image). Signs indicate products / services. According to the researches carried out, "While today's products and services of brands are forty percent for consumers, the image and perception that brands have in consumers are sixty percent for consumers" (Tan, 2017: 17). Marx draws attention to the products created by human hands and the importance of these products and goods to the persons, Belk claims that the products and goods are the extended self of the persons, and it is necessary to question how these products become a part of their self. It is emphasized that the relationship between commodities and people in the study is a communication and interaction not only from the people but also from the metal to the persons. Brand managers also use public relations, advertising and integrated marketing communication applications to have a brand image. "In this way, image management is carried out and it is aimed to achieve success by creating an impression of the images desired by society." (Bulduklu, 2015: 37). Brands are managing the image with public relations, advertising and integrated marketing communication applications. According to Fortsyth (2009: 151) and Keller (2013: 246), "public relations must first and foremost consider the institution, the institution's brand, or the various products designed and imagined to enhance the image of the brand's product". Kotler (2000: 111) says, "Most of the role of public relations costs are reliable investments designed to create a positive image of the target market." According to Budak \& Budak, "it is more correct to use the concept of image engineering instead of relations with the people". (Budak \& Budak, 2014: iv). Authors draw attention to the relationship between public relations and brands. Williamson refers to advertising and image relations as "the images we see in advertisements that give meaning to advertisements and convey their own meaning to the product. That's why advertising is so uncontrollable." (Williamson, 2000: 182). In Gombrich's Image and Eye, he says, "The real value of imgen is the power to transmit information that can not be coded in any other way" and supports Williamson's view. Harris \& Whalen says "The idea behind integrated marketing communications is that everything that consumers are exposed to the product is summed up on a single brand image." (Harris \& Whalen, 2009: 41). Ozdemirci explains the relationship between the company, marketing and brand management with the image by referring to the crises of 1929, 1973 and 2008 and describes the rise of marketing communication as the age of image starting with 1973 (Özdemirci, 2014). Public relations have brand images with advertising and integrated marketing communication applications. Thus, "people have the identity, the image they desire and the statues they desire with their products and services" (Tan, 2017: 20). Fiske talks about the concept of ego-drive in his Introduction to Communication Studies. "Social psychologists talk about ego-drive, which means our own being needs to be recognized, recognized and accepted" (Fiske, 2015: 88). Brand and people want to have images for awareness, recognition, acceptance. According to the Marxist view, this is the case with the concepts of "alienation" and "commodity fetishism"; According to Jacques Ellul, Critical Approach Representatives, "Technology Society (2003)" and "Word Fall (2015)"; According to Herbert Marcuse, "One Dimensional Man (1990)"; According to Theodor W. Adorno, "Cultural Industries, Cultural Management (2014); According to Erich Fromm, "To Have or To Be (2015); According to Guy Debord, "The Performing Society (2014); According to Jean Baudrillard, "Consumption Society (2013). As explained above, in order to influence the individuals in the brands, the media takes place and image method is applied in the practice of life, with public relations, advertising and integrated marketing communication applications. Adorno emphasizes that this is done with culture industry (brand image methods) and culture management. When Fromm says in his work "To Have or To Be" that the image of the object (object / product) and the object has become "a sign of the self and the power of influencing one's other" (Fromm, 2015: 99), Baudrillard says that "people are consuming signs, not the products" (Baudrillard, 2009). Critical approaches point to the effects of the media and the brands' image management, in other words the concepts and techniques and practices of the public relations and integrated marketing communication. In other words, critical approaches attract attention not only to the objects but also to the interaction and communication process from the objects to the persons. 


\section{Discussion}

Erdoğan \& Alemdar The Other Theory (2002) emphasizes in the historical heading of technology-mediated communication that "the development of the media is not a coincidence and is a result of intensive laboratory research in this development". Much research has been done on the effects of the media. It has even been developed on a number of theories on media effects. Some of the theories on media affirm media influences, while others do not. The question centered on "Uses and Gratifications Approach" is why do people use the media? And what do people use the media for? (McQuail, 2005: 424 Uses and Gratifications Approach "put forward the argument of active audience" (Erdoğan, 2014: 148). According to the establishment, people use media to satisfy needs, in other words diversion, personal relationships, acquisition and consolidation of personal identity / self, and surveillance. The relation between social media and image-self can be explained as follows: "The end of every social relationship satisfies a certain need. Attachment, love, care, uncertainty reduction are the consequences of satisfying this need " (..) "Possible consequences of satisfying social relationships include satisfying the needs of love and interest and developing self-concept, affirming self-image, reducing uncertainty, and creating an impression" (Ertürk, 2010: 111-240). In the study, it is tried to explain the usage of new media and social media, the use - self - image relationship and the transformation of image, self - relation, interaction, cooperation and communication. Integrated marketing communication is based on the concepts of need, satisfaction, use, object / conceptual relationship with the visual / visual image, dependence / dependency, and the finalization of the essential requirements or requirements. This explains why integrated marketing communications have been effective over the past six decades. Maletzke points out two aspects of the media in his model. These are "the image that the buyer has about the media tool and pressure or force from the media" (McQuail \& Windahl, 2010, 64). According to Güngör, the Maletzke model declares, "It is important in bringing people forward in communication, but also in emphasizing the power of mass media." Maletzke draws attention to image of media. On the other hand, Gerbner emphasizes the cultural change brought about by the theories of cultivation and the media's co-operation with the brands with the following sentence: "All mass media are market oriented" (Gerbner, 2014: 191). On the other hand, as Aristotle says, "people want to know". In addition to these, people want to reunite with a mediated communication (media) by referring to the Babylonian metaphor.

\section{Results}

It is observed on the interest, use and penetration of social media that it is not mere verbal connection between the terms of common, community, interaction, collaboration and communication. Freud links it to common bonds and bonds characteristic features if people create a mass among themselves. Social media has two-sided, interactive, participatory and sharing characteristics. Thus, the definition and characteristics of communication are realized in social media. The interest, use and penetration to social media are explained by some thinkers, by technological approach, by some thinkers by socio-psychological and / or psychological approach and by critical approach by critical thinkers. This work is considered as a holistic approach. As mentioned in the study, people are not indifferent to objects, products and furniture produced by human hands. Marx explains this as "manmade products are transformed into an independent entity in the process"; Referring to McLuhan Blake, "people are turning to what they see"; Russel Belk explains it as "we are what we have." New and social media is an interactive, participatory, participatory, virtual and measurable communication environment. It can be observed that people turn towards the characteristic features of the media. Messages and relationships can be digitized and measured with the ability of new media to have virtual identity, personality, self, to measure new media, such as concrete (as smart mobile phones) and abstract (as software-social media channel) objects, products and goods. People also want to have images that have new media tools. On the other hand, both personal and brands use both social relations, imagery and images of objects to be a "self" and to create awareness. As Goffman points out, the concepts of image and self are intrinsic to the person. The methods that people use to create a positive impression are explained as the presentation of the self, in other words, as image management. Aristotle explains this to Nikomakhos Ethic not to dominate himself in his work (1998). And it goes on to say, "Therefore, it must be accepted that non-sovereigns are acting like theatrical actors" (Aristotle, 1998: 135). We understand that the concepts of role, actor and theater are also present in the Ancient Age. These concepts are described by the representatives of the Chicago School as a symbolic approach. The symbolic interaction in social networks is realized through the use of symbols, images and demonstrations with the aid of tools such as photographs and videos (without temporal cohesion, but spatial and temporal unity in Gofmann's research). Intermediate 
communication (media) technology is transforming into an intermediary communication. And again, the gestures that Mead, Goffman stand on, and their meanings stand out in the social media. In addition to this, people want to interact and collaborate with other groups, groups, communities, even the global community. With the social media not having gatekeepers, being bi-directional, allowing interaction and sharing, people in the global world are gathering under the roof of social media and referring to the Babel Tower metaphor. Critical approachers emphasize that society is transformed into technological, one-dimensional, consumption and demonstration society. With globalization, it is accepted by thinkers that the situation has spread all over the world.

The brand consists of tangible and abstract values, and abstract values are realized through advertising, public relations and integrated marketing communication techniques, tactics, methods and applications. In the study, it is emphasized that the person-object relation is an interaction, communication process from object to person, not just from person to object. It can be observed that marketing and brand management are not indifferent to social media. When we think that the origin of marketing concept is the market, we can say that these people are marketing where there is a mass created. Marketing, brand managers can reach both direct and massive people with new and social media's interactive, shared, participatory, virtual and measurable properties. Thus, brands can have awareness, recognition and positive images.

Social media is becoming both personal and brand image management with the features of interaction, participation, sharing, digitization, measurability and virtuality. While the people in social media channel manage the image with dramaturgy and impression management, the brands manage the image through public relations, advertisement and integrated marketing communication applications. Symbolic interaction practices in personal and brand image management stand out. We think that it is important for the study of communication to show the transformation of the research subject media. The work is expanded by using survey, focus and semiotic methods in the thesis.

\section{References}

[1] Aristoteles. (2016). Retorik, çev: Doğan, M. İstanbul: Yapı Kredi Kültür Sanat Yayıncılık.

[2] Aristoteles. (1998). Nikomakhos'a Etik, çev: Babür, S. Ankara: Ayraç Yayınevi.

[3] Adorno T. W. (2014). Kültür Endüstrisi-Kültür Yönetimi, çev: Ülner, N. Tüzel, M. \& Gen E. İstanbul: İletişim Yayınları.

[4] Baron, A. B. \& Byrne D. (1997). Social Psychology, A Viacom Company, Printed in the United States of America,

[5] Baştan, S. (2009). Kuramdan Uygulamaya Etkileşimli Illetişim Tasarımı, Ankara: Nobel Yayın.

[6] Baudrillard, J. (2009). Gösterge Ekonomi Politiği Hakkında Bir Eleştiri, çev: Adanır O. \& Bilgin, A. İstanbul: Boğaziçi Üniversitesi Yayınevi.

[7] Baudrillard, J. (2013). Tüketim Toplumu, çev: Deliceçaylı, H. \& Keskin, F. İstanbul: Ayrıntı Yayınları.

[8] Belk, R. (1988). "Possessions and the Extended Self", Journal Of Consumer Research, Vol.15. September. pp: 139-168.

[9] Belk. R. (1989). "Extended Self and Extending Paradigmatic Perspective" Journal Of Consumer Research, Vol. 16. June. pp: 129-132.

[10] Belk, R. (2013). "Extended Self in a Digital World", Journal Of Consumer Research, Vol.40. No.3. October. pp: 477-500.

[11] Berger, A. A. (2012). Kültür Eleştirisi, Kültürel Kavramlarına Giriş, çev: Emir, Ö. İstanbul: Pinhan Yayıncılık.

[12] Bourse, M. \& Yücel, H. (2012). İletişim Bilimlerinin Serüveni, İstanbul: Ayrıntı Yayınları.

Binark, M. (2014). Yeni Medya Çalışmalarında Araştırma Yöntem ve Teknikleri, drl. Binark, M. İstanbul Ayrıntı Yayınları.

[13] Briggs, A. \& Burke, P. (2004). Medyanın Toplumsal Tarihi, çev: Şener, İ. İstanbul: İzdüşüm Yayınları. Budak, G. \& Budak, G. (2014). İmaj Mühendisliği Vizyonundan Halkla İlişkiler, Ankara: Nobel Akademik Yayıncılık.

[14] Bulduklu, Y. (2015). İmaj Yönetimi, Yaklaşımlar, Taktikler, Stratejiler, Konya: Seba Ofset Matbaacılık, Literatürk Academia,

[15] Cohen, J. B. (1989). “ An Over - Extended Self?” Journal Of Consumer Research, Vol. 16. No. 1. pp: 125-128.

[16] Debord, G. (2014). Gösteri Toplumu, çev: Ekmekçi, A. ve Taşkent, O. İstanbul Ayrıntı Yayınları.

[17] Eco, U. (2009). Avrupa Kültüründe Kusursuz Dil Arayışı, çev: Atakay, K. İstanbul: Literatür Yayıncılık.

[18] Ellul, J. (2003). Teknoloji Toplumu, çev: Ceylan, M. İstanbul: Bakış Yayınları.

[19] Ellul, J. (2015). Sözün Düşüşü, çev: Arslan, H. İstanbul: Paradigma Yayıncılık.

[20] Erdoğan, İ. (2014). Medya Teori ve Araştırmaları, Ankara: Erek Matbaacılık.

[21] Erdoğan, İ. \& Alemdar, K. (2002). Öteki Kuram, Ankara: Pozitif Matbaacılık.

[22] Ertürk, Y. D. (2011). Sosyal Psikoloji Ders Notları, İstanbul Üniversitesi İletişim Fakültesi, İstanbul. 
[23] Ertürk, Y. D. (2010). Davranış Bilimleri, İstanbul: Kutup Yıldız Yayınları.

[24] Fiske, J. (2015). İletişim Çalışmalarına Giriş, çev: İrvan S. Ankara: Pharmakon Yayınevi.

[25] Forsyth, P. (2009). Marketing, A Guide To The Fundamentals, The Economist In Association Profile Books Ltd. London.

[26] Freud, S. (2012). Kitle Psikolojisi, çev: Şipal, K. İstanbul: Cem Yayınevi.

[26] Fromm, E. (2015). Rüyalar Masallar Mitler, çev: Arıtan, A. ve Ökten, K. İstanbul: Say yayınları. (Özgün adı: The Forgotten Language. An Introduction to the Understanding of Dreams Fairy Tales and Myths).

[27] Fromm, E. (2015b).Sahip Olmak ya da Olmak, çev: Arıtan, A.İstanbul Say Yayınları.(Özgün adı:To Have or $\mathrm{To} \mathrm{Be})$.

[28] Fuchs, C. (2016). Sosyal Medya: Eleştirel Bir Giriş, çev: Saraçoğlu, D. \& Kalaycı, İ. Ankara: NotaBene Yayınları.

[29] Gerbner, G. (2010). “Kitle İletişimin Araçları ve İletişim Kuramı”, Kitle İletişim Kuramları, çev: Mutlu, E. drl: Mutlu, E. Ankara: Ütopya Kitabevi, s: 75-100.

[30] Gerbner, G. (2014). Medyaya Karşı, İstanbul: Ayrıntı Yayınları.

[31] Goffman, E. (1978). The Presentation of Self in Everyday Life, Penguin Books Ltd. Made and printed in Great Britain by Cox \& Wyman Ltd, London. Goffman, E. (2014). Günlük Yaşamda Benliğin Sunumu, çev: Cezar, B. İstanbul: Metis Yayıncılık.

[32] Gombrich, E. H. (2015), İmge Ve Göz, çev: Atakay, K. İstanbul: Yapı Kredi Yayınları. (Orginal title: The Image and the Eye, 1982, Phaidon Press Limited)

[33] Guiraud, P. (1990). Göstergebilim, çev: Yalçın, M. Sivas: Önder Matbaacılık ve Gazetecilik Ofset, .y. özel yayım (Özgün adı: La semiologie, Presses Universitaires de France, Paris, 1971).

[34] Güney, S. (2012). Sosyal Psikoloji, Ankara: Nobel Akademik Yayıncılık.

[35] Güngör, N. (2013). İletişim Kuramlar ve Yaklaşımlar, Ankara: Ekinoks Yayın Dağıtım.

[36] Habermas, J. (1996). İletişimsel Eylem Kuramı 1.Cilt Eylem Rasyonelliği ve Toplumsal Rasyonelleşme 2. Cilt İşlevselci Aklın Eleştirisi Üzerine, çev: Tüzel, M. İstanbul: Kabalcı Yayınevi.

[37] Harris, T. L. \& Whalen, P. T. (2009) 21.Yüzyılda Pazarlama Profesyonelinin Halkla İlişkiler El Kitabı, çev: Görpe, S. İstanbul: Rota Yayınları.

[38] Kağıtçıbaşı, Ç. (2009). Family, Self, and Human Development Across Cultures, Theory and Applications, United States of America: Psychology Press.

[39] Kağıtçıbaşı, Ç. \& Cemalcılar, Z. (2015). Dünden Bugüne İnsan ve İnsanlar, Sosyal Psikolojiye Giriş, İstanbul: Evrim Yayınevi.

[40] Kara, T. (2013). Sosyal Medya Endüstrisi, İstanbul: Beta Basım Yayın.

[41] Keller, K. L. (2013). Strategic Brand Management, 4e, Pearson Education Limited, England.

[42] Kotler, P. (2000) Kotler On Marketing, Simon\&Schuster UK Ltd. London.

[43] Lang, K. (2010). İletişim Araştırmaları: Kökenleri ve Gelişmesi, Kitle İletişim Kuramları,çev: Mutlu, E. drl:

[44] Mutlu, E. Kitle İletişim Kuramları, Ankara: Ütopya Kitabevi, s: 27-41.

[45] Lazar, J. (2009). İletişim Bilimi, çev: Anık, C. Ankara: Vadi Yayınları.

[46] Marcuse, H. (1990). Tek Boyutlu İnsan, çev: Yardımlı, A. İstanbul: İdea Yayınları.

[46] Mattelart, A. \& Mattelart, M. (2011). İletişim Kuramları Tarihi, çev: Zıllıoğlu, M. İstanbul: İletişim Yayınları.

[47] McLuhan, M. (2014). Gutenberg Galaksisisi, çev: Güven, G. Ç. İstanbul: Yapı Kredi Kültür Sanat Yayıncilık.

[48] McLuhan, M \& Powers, B. R. (1992). The Global Village, Oxford University Press, United States of America.

[49] McLuhan, M \& Fiore, Q. (2012). The Medium is the Massage (Medya Mesajı Medya Masajıdır) çev: Haydaroğlu, İ. İstanbul: Mediacat Kitapları.

[50] McQuail D. (2006). McQuail's Mass Communication Theory, (Fifth Edition), Sage Publications Ltd. Printed in Great Britain by The Alden Press, Oxford.

[51] McQuail, D. \& Windahl, S. (2010). İletişim Modelleri -Kitle İletişim Çalışmalarında-, çev: Yumlu, K. Ankara: İmge Kitabevi Yayınları.

[52] Morva, O. (2013). Chicago Okulu, İstanbul: Doruk Yayımcılık.

[53] Özdemirci, A. (2012). Popüler Kültür, Tüketim Psikolojisi ve İmaj Yönetimi: Türkiye (1950-1980), İstanbul: Beta Yayınları.

[54] Özer, S. (2014). Genişletilmiş Benlik Teorisi (The Extented Self Theory), ed. Yağcı, İ. M ve Çabuk, S. Pazarlama Teorileri, İstanbul: MediaCat Kitapları, s: 418-455.

[55] Piercy, J. (2013). Semboller, Evrensel Bir Dil, çev: Tuna, U. D. İstanbul: Aykırı Yayıncılık.

[55] Polat, S. \& Arslan, Y. (2015). Örgütsel Yaşamda İmaj: İmaj Geliştirme ve Yöntemi, Ankara: Nobel Akademik Yayıncılık.

[56] Rifat, M. (2014b). XX. Yüzyılda Dilbilim ve Göstergebilim Kuramları 2.Temel Metinler, İstanbul: Yapı Kredi Kültür Sanat Yayıncılık.

[57] Ritzer, G. (2011). Modern Sosyoloji Kuramları, çev: Hülür, H. Ankara: De Ki Basım Yayım.

[58] Ritzer, G. \& Stepnisky, J. (2014). Sosyoloji Kuramları, çev: Hülür, H. Ankara: De Ki Basım Yayım.

[59] Tan, H. (2017). İtibar Kavramında Reklamın Önemi ve Reklamın Marka Dünyasına Etkisi, İstanbul Aydın Üniversitesi Dergisi, Nisan, Vol. 9. s:1-23.

[60] Tasner, M. (2011).Anında Pazarlama, Web 3.0 Pazarlama Klavuzu, çev: Özer, A. İstanbul: MediaCat Kitapları.

[61] Thompson, B. J. (2010) “Kitle İletişimin Bazı Özellikleri”, Kitle İletişim Kuramları, çev: Mutlu, E. drl: Mutlu, E. Ankara: Ütopya Kitabevi, s:210-220. 
Communication and Technology Congress - CTC 2017 (November 2017 - Turkey, Istanbul)

[62] Tokgöz, O. (2015). İletişim Kuramlarına Anlam Vermek, Başlangıcından Günümüze Anglo-Amerikan İletişim Kuramı, Ankara: İmge Kitabevi.

[63] Tosun, N. B. (2010). İletişim Temelli Marka Yönetimi, İstanbul: Beta Basım Yayım.

[64] Vardar, B. (1999). XX. Yüzyıl Dilbilimi (Kuramcılardan Seçmeler), İstanbul: Multilingual.

[65] Wallace, R. A. \& Wolf, A. (2015). Çağdaş Sosyoloji Kuramları, Klasik Geleneğin Gelişmesi, çev: Elburuz, L. \& Ayas, M. R. Ankara Doğu Batı Yayınlar.

[66] Williamson, J. (2001). Reklamların Dili, Reklamlarda Anlam ve İdeoloji, çev: Fethi, A. Ankara: Ütopya Yayınevi.

[67] URL-1 http://www.sozcu.com.tr/2016/teknoloji/facebook-kullanici-sayisini-acikladi-1331859/ (10.01.2017). 